\title{
Analisis Kinerja Rentabilitas dan Solvabilitas Sektor Kosmetik dan Rumah Tangga (Studi Kasus Perusahaan yang Terdaftar di Bursa Efek Indonesia)
}

\author{
Ima Halimah \\ Fakultas Ilmu Administrasi dan Humaniora, Universitas Muhammadiyah Sukabumi, Sukabumi \\ e-mail:Imahalimahrdwn@gmail.com \\ Nor Norisanti \\ Fakultas Ilmu Administrasi dan Humaniora, Universitas Muhammadiyah Sukabumi, Sukabumi \\ e-mail:nor_norisanti@yahoo.com
}

Faizal Mulia Z.

Fakultas Ilmu Administrasi dan Humaniora, Universitas Muhammadiyah Sukabumi, Sukabumi e-mail:faizal_88@ummi.ac.id

\begin{abstract}
This study discusses the analysis of capital structures that measure rentability and solvability in Cosmetics and Household sub-sector. This research uses descriptive method, the data used are financial statements of cosmetics companies for the period 2015 to 2017. The results showed that good financial performance was PT. Unilever Indonesia Tbk. because the calculation of rentability and solvability was able to exceed the average value of the industry while companies with poor financial performance were PT. Kino Indonesia Tbk. and PT. Mustika Ratu Tbk. because the calculation for the ratio cannot exceed the industry average value.
\end{abstract}

Keywords: Financial Performance, Rentability, Solvability.

\section{PENDAHULUAN}

Pertumbuhan pasar kosmetik di Indonesia periode 2015 hingga 2017 mengalami peningkatan dan penurunan, Pada jangka waktu enam tahun, Kementerian Perindustrian menyatakan pertumbuhan pasar sebesar 9,67 persen dan di kuartal $\mathrm{I} / 2018$ telah mencapai 7,36 persen. Hal ini membuktikan bahwa sektor kosmetik menjadi perusahaan dengan kinerja pertumbuhan pasarnya bergerak mengikuti pertumbuhan ekonomi nasional. Perkembangan kondisi ini disampaikan oleh Airlangga Hartanto selaku Menteri Penrindustrian (MENPERIN).

Kosmetik merupakan hal yang tidak asing terdengar oleh setiap kaum wanita dan pria, yang mana dalam pemakaiannya yang menjadikan bisnis kosmetik ini memiliki nilai estetika tersendiri. Dalam hal ini, kaum wanita merupakan target industri kosmetik dan menandakan bahwa bisnis kosmetik merupakan bisnis yang mengacu pada kebutuhan masyarakat yang sehari-harinya menggunakan campur tangan aneka ragam produk kosmetik.

Bisnis kosmetik dipersepsikan berbagai macam oleh masyarakat, namun perlu diketahui bahwa bisnis kosmetik tidak hanya mencakup riasan yang digunakan pada wajah tapi juga mencakup perawatan pada tubuh. Produk-produk kosmetik bila ditinjau dari perspektifnya dikategorikan Skin Care, Hair Care, Fragrances, Suncare dan Personal Hygiene. Contoh dari produk kosmetik juga meliputi sabun, lulur, sampo, kondisioner, parfum, pewarna rambut, gincu, perona bibir, pasta gigi, obat kumur, sikat gigi, serta deodorant.

Tujuan sebuah perusahaan dalam upayanya mengembangkan usaha adalah 
menghasilkan keuntungan demi memenuhi setiap kegiatan operasionalnya. Dengan mendapatkan keuntungan yang maksimal maka dapat digunakan sebagai tolak ukur kesuksesan perusahaan dalam meramalkan kesempatan di tahun selanjutnya dan menjadi faktor pendukung di segala kemungkinan yang akan terjadi.

Laba perusahaan diperoleh dari aktivitas berbisnis dengan melakukan penjualan produk-produk yang ditawarkan kepada kosumen melalui media informasi. Namun hasil observasi menunjukkan perusahaanperusahaan dalam subsektor kosmetik mengalami kondisi terjadinya peningkatan utang yang tidak diimbangi dengan perolehan laba. Rata-rata perusahaan kosmetik mengalami kenaikan pada tingkat utang dengan persentase pada tahun 2015 hingga 2016 sebesar 8,8\% dan pada tahun 2016 hingga 2017 sebesar 12,3\%. Kondisi ini menyimpulkan bahwa rata-rata tiap tahunnya utang perusahaan mengalami peningkatan disebabkan adanya dana tambahan dari pihak luar. Penambahan utang ini membuat modal perusahaan mengalami perubahan sehingga dalam menjalankan kegiatannya mengalami perkembangan, karena jumlah kewajiban (utang) menunjukkan sejauh mana dana yang dipinjam telah digunakan untuk membeli aset dan hutang yang diciptakan tidak seimbang dengan laba yang dihasilkan oleh perusahaan.

Rata-rata laba bersih yang diperoleh perusahaan kosmetik pada tahun 2015 hingga 2017 dinilai mengalami peningkatan dari pergerakannya. Pada tahun 2015 hingga 2016 kenaikan laba mencapai $1,44 \%$, dan kemudian mengalami peningkatan kembali di tahun 2016 hingga 2017 yang mencapai 8,13\%. Kondisi ini salah satunya karena hutang yang terus mengalami peningkatan setiap tahunnya, Namun jika dilihat banyaknya perusahaan yang mengalami fluktuasi, hal ini dapat dipengaruhi oleh tingkat pembelanjaan dan kegagalan mendapatkan pendanaan sehingga perusahaan menjadi kurang memaksimalkan pendapatannya dan sekaligus kurang mampu meminimalkan segala bentuk biaya yang harus ditanggung perusahaan.
Rata-rata ekuitas yang dimiliki pemegang saham perusahaan kosmetik mengalami peningkatan, dengan persentase pada tahun 2015 hingga 2016 sebesar 1,85\%, sedangkan pada tahun 2016 hingga 2018 sebesar $6,8 \%$. Kondisi ini dikarenakan bisnis kosmetik semakin diminati masyarakat, sehingga banyak masyarakat tertarik untuk melakukan penanaman modal dengan membeli saham perusahaan kosmetik yang terdaftar di Bursa Efek Indonesia (BEI).

Dana yang terdapat di struktur permodalan biasa digunakan untuk membiayai kegiatan investasi perusahaan dengan jenis investasi lainnya. Keputusan pendanaan memadukan modal yang dipakai pada utang dengan pembiayaan investasi oleh ekuitas. Bambang (2008) menyatakan bahwa struktur modal merupakan perbandingan antara modal asing (utang) dengan modal sendiri. Sumber modal dapat berasal dari modal sendiri di lingkungan internal perusahaan, sementara modal asing yang berupa utang diperoleh dari lingkungan eskternal perusahaan.

Struktur modal yang terdapat dalam perusahaan dapat dianalisis dengan menggunakan analisis horizontal, dan diukur melalui rentabilitas menggunakan perhitungan return on equity serta melalui solvabilitas menggunakan perhitungan rasio utang terhadap ekuitas dan rasio utang jangka panjang terhadap ekuitas. Hasil-hasil perhitungan tersebut selanjutnya dideskripsikan melalui perhitungan rata-rata industri dari setiap rasio tersebut.

Return on Equity (ROE) digunakan menilai bagaimana modal sendiri menjadi efisien dengan melakukan pembagian jumlah laba bersih yang dimiliki perusahaan dibandngkan ekuitas yang dimiliki, sehingga akan terlihat bahwa berapa persen dari keuntungan jika dihitung dari ekuitas sebab nilainya semakin besar semakin baik bagi perusahaan.

Debt to Equity Ratio (DER) digunakan untuk menilai bagaimana ekuitas dapat dikelola untuk membayar utang-utang terhadap pihak luar. Semakin kecil nilai rasio ini menunjukkan bahwa semakin baik 
perusahaan dalam mengukur dana dari kreditor dan modal perusahaan melalui perhitungan hutang dibagi dengan ekuitas. Sedangkan rasio utang jangka panjang atas ekuitas dipakai dalam proses perhitungannya merupakan bentuk perputaran (kali) untuk menunjukkan berapa rupiah utang jangka panjang dijamin dengan ekuitas.

Penelitian mengenai analisis struktur modal dalam mengukur rentabilitas dan solvabilitas ini merupakan replikasi atas studi yang dilakukan oleh Chikashi (2013) dengan mengaplikasikan perhitungan ROE dan DER, dimana hasil penelitiannya menunjukkan bahwa peningkatan utang memiliki pengaruh terhadap keuntungan perusahaan. Selanjutnya, Amargit et al. (2011) meneliti mengenai dampak struktur modal dalam profitabilitas melalui perhitungan utang jangka pendek terhadap aset dan ROE, dengan memperoleh hasil bahwa struktur modal mempengaruhi tingkat profitabilitas dikarenakan bunga dapat mengurangi beban pada pajak sebagai konsekuensi dari tingkat penghasilan laba yang bergantung pada berbagai hutang yang diciptakan.

Penelitian ini memiliki tujuan untuk menelaah bagaimana analisis struktur modal dalam mengukur rentabilitas dan solvabilitas pada perusahaan-perusahaan dalam sub sektor kosmetik pada kondisi terjadinya peningkatan utang yang tidak diimbangi dengan perolehan laba. Dengan dasar pemikiran tersebut, peneliti melakukan studi mengenai analisis struktur modal dalam mengukur rentabilitas dan solvabilitas pada perusahaan-perusahaan sub sektor kosmetik yang terdaftar di BEI.

\section{Pengertian Struktur Modal}

Kekayaan yang berada pada perusahaan berkaitan dengan pengambilan keputusan manajemen keuangan untuk menentukan pengalokasian dana melalui bentuk-bentuk pembelanjaan atas kebutuhan perusahaan. Menurut Bambang (2008), struktur modal merupakan porposi utang jangka panjang dengan modal. Oleh karenanya, perusahaan harus memiliki modal dan utang yang memiliki resiko seimbang dan struktur modal Menurut Putra (2009). struktur modal adalah campuran antara modal asing dan ekuitas untuk mendanai kegiatan perusahaan.

Pertumbuhan yang dicapai perusahaan mengakibatkan modal perusahaan harus mengalami peningkatan. Hal ini agar perusahaan mendapatkan laba yang maksimal dan dapat memenuhi kewajibannya. Sumber pendanaan yang berpengaruh pada laba perusahaan ditentukan melalui pemilihan penggunaan laba, ekuitas dan utang.

\section{Pengertian Rasio Rentabilitas}

Rentabilitas adalah kinerja perusahaan menciptakan laba atau keuntungan pada periode tertentu dengan menggunakan modal sendiri maupun modal asing (Hery, 2015; Kasmir, 2015). Jenis-jenis rasio rentabilitas adalah rasio Pertumbuhan, Profit Margin (Profit Margin on Sale), Laba perlembar saham (Earning Per Share), rasio Hasil Pengembalian atas Ekuitas (Return on Equity), serta rasio Hasil Pengembalian atas Investasi (Return on Investment).

Pengukuran kinerja keuangan dari perusahaan menggunakan perhitungan hasil pengembalian ekuitas memiliki alasan bahwa tingkat pengukurannya dapat menunjukkan bagaimana modal sendiri menjadi lebih efisien. Oleh karena itu, Return on Equity digunakan untuk dalam mengukur tingkat rentabilitas perusahaan. Rentabilitas ini dilakukan dengan membagi laba bersih perusahaan dengan modal sendiri, dimana semakin tinggi nilai yang tercantum maka semakin baik pengembalian ekuitas di perusahaan. Hal ini sesuai dengan pernyataan Kasmir (2015) dimana artinya posisi pemilik perusahaan semakian berpengaruh dalam dunia industry. Hal ini disebabkan dalam struktur modal penggunaan hutang yang semakin besar akan meningkatkan ROE perusahaan (Sartono, 2014).

Menurut pendapat Mardiyanto (2009), struktur modal akan menentukan hasil modal sendiri atau ROE. Dalam kondisi bisnis yang buruk, struktur modal yang lebih banyak menggunakan modal utang tinggi akan mempercepat perusahaan mengalami tekanan kebangkrutan; sebaliknya dalam kondisi bisnis yang baik, menggunakan modal utang 
tinggi akan bisa mempercepat perkembangan perusahaan.

\section{Pengertian Rasio Solvabilitas}

Rasio solvabilitas menurut Kasmir (2015) menunjukkan kemampuan perusahaan untuk membayar seluruh kewajibannya. Artinya, rasio ini digunakan untuk mengukur beban utang yang harus dibayar perusahaan dalam memenuhi kebutuhannya. Jenis-jenis perhitungan rasio dalam Kasmir (2015) adalah: (1) Rasio utang jangka panjang terhadap modal (LTDtER); (2) Rasio utang terhadap modal (DER); (3) Rasio utang terhadp aset (DAR); (4) Current Liabilities To Net Worth (CLNW); (5) Times Interest Earned (TIE); serta (6) Fixed Charge Coverage (FCC).

Menurut Harmono (2011), indikator umum dalam menentukan komposisi struktur modal dapat dihitung melalui rasio utang terhadap modal (DER) dan rasio utang jangka panjang terhadap modal (LTDtER). DER dilakukan membagi total hutang dengan total ekuitas untuk menilai berapa jumlah dana yang dijadikan sebagai jaminan utang. Hal ini sesuai dengan pernyataan Kasmir (2015). Sedangkan perhitungan utang jangka panjang terhadap modal (LTDtER) digunakan untuk mengetahui berapa besaran modal yang dijaminkan untuk utang jangka panjang perusahaan dengan melakukan pembagian total utang jangka panjang dengan ekuitas.
Perusahaan dengan proses pengelolaan manajemen keuangan dengan kondisi struktur modal yang lebih banyak menggunakan hutang dalam operasinya bisa mengalami beban bunga yang akan menurunkan laba bersih. Sebagaimana dikemukakan Brigham dan Houston (2010), dengan adanya pemakaian utang yang tinggi maka laba akan mengalami penurunan; sebaliknya, jika pemakaian utang rendah maka laba akan mengalami peningkatan.

Penggunaan utang dalam perusahaan mempengaruhi kondisi keuangan perusahaan serta kelangsungan hidup perusahaan yang dapat diprediksi, sehingga resiko bisnis dapat dikalkulasikan. Selanjutnya, dengan memiliki persentase modal dan utang dimana tingkat return dan resiko berada dalam posisi relatif seimbang maka akan terciptanya struktur modal yang optimal.

\section{METODE PENELITIAN}

Obyek yang digunakan dalam analisis struktur modal untuk mengukur rentabilitas dan solvabilitas pada perusahaan-perusahaan subsektor kosmetik yang terdaftar di BEI. Data yang digunakan adalah data sekunder berupa laporan keuangan dari website resmi BEI (www.idx.com) periode 2015-2017 dan studi kepustakaan dengan penggunaan metode deskriptif.

Tabel 1. Definisi Operasional Variabel

\begin{tabular}{|c|c|c|c|}
\hline Variabel & Dimensi & Indikator & Konsep \\
\hline $\begin{array}{l}\text { Struktur Modal } \\
\text { (Mardiyanto, } \\
\text { 2009) }\end{array}$ & Neraca & $\begin{array}{l}\text { - Liability } \\
\text { - Equity }\end{array}$ & $\begin{array}{l}\text { Komposisi dan proporsi utang jangka } \\
\text { panjang dan ekuitas }\end{array}$ \\
\hline $\begin{array}{c}\text { Rentabilitas } \\
\text { (Kasmir, 2015) }\end{array}$ & $\begin{array}{l}\text { Return on Equity } \\
\quad(\mathrm{ROE})\end{array}$ & $\begin{array}{l}\text { - Laba Bersih } \\
\text { - Ekuitas }\end{array}$ & $\begin{array}{l}\text { Rasio yang dihitung dengan membagi } \\
\text { laba bersih dengan ekuitas yang ada. }\end{array}$ \\
\hline \multirow{2}{*}{$\begin{array}{c}\text { Solvabilitas } \\
\text { (Kasmir, 2015) }\end{array}$} & $\begin{array}{l}\text { Debt to Equity } \\
\text { Ratio (DER) }\end{array}$ & $\begin{array}{l}\text { - Total Utang } \\
\text { - Total Ekuitas }\end{array}$ & $\begin{array}{l}\text { Rasio yang dihitung dengan } \\
\text { membandingkan total hutang } \\
\text { dengan total ekuitas. }\end{array}$ \\
\hline & $\begin{array}{l}\text { Long Term Debt } \\
\text { to Equity Ratio } \\
\text { (LTDtER) }\end{array}$ & $\begin{array}{l}\text { - Utang Jangka } \\
\text { Panjang } \\
\text { - Total Equity }\end{array}$ & $\begin{array}{l}\text { Rasio yang dihitung dengan hasil bagi } \\
\text { utang jangka panjang dan total } \\
\text { ekuitas. }\end{array}$ \\
\hline
\end{tabular}

Sumber: Data Diolah, 2019 
Analisis horizontal digunakan sebagai metode analisis data dalam menganalisis struktur modal yang diukur melalui rasio rentabilitas dan rasio solvabilitas. Rentabilitas menggunakan rasio Return on Equity (ROE), yaitu perbandingan antara nilai laba bersih terhadap nilai total ekuitas. Solvabilitas menggunakan dua rasio, yaitu rasio Debt to Equity (DER) dan rasio Long-term Debt to Equity (LTDER). DER dihitung sebagai perbandingan antara total hutang terhadap total ekuitas; sementara LTDER merupakan perbandingan antara nilai total utang jangka panjang terhadap nilai total ekuitas. Hasil perhitungan atas ketiga rasio menggunakan unit persentase. Definisi operasional variabel dirangkum dalam Tabel 1.

\section{HASIL ANALISIS}

Berdasarkan data laporan tahunan yang telah dikeluarkan oleh ADES, KINO, TCID, MBTO, MRAT dan UNVR melalui Bursa Efek Indonesia berupa laporan tahunan perusahaan selama tiga tahun terhitung tahun 2015 sampai tahun 2017. Dalam hal ini, struktur modal menggunakan rasio ekuitas terhadap total asset yang diperuntukkan untuk mengetahui bagaimana posisi struktur modal dalam periode tiga tahun.

Tabel 2. Rasio Ekuitas terhadap Total Asset Perusahaan Kosmetik di BEI Periode 2015 hingga 2017 (dalam persentase)

\begin{tabular}{lccc}
\hline \multicolumn{1}{c}{ Nama Perusahaan } & $\mathbf{2 0 1 5}$ & $\mathbf{2 0 1 6}$ & $\mathbf{2 0 1 7}$ \\
\hline PT. Akasha Wira International Tbk. (ADES) & 50 & 50 & 51 \\
\hline PT. Kino Indonesia Tbk. (KINO) & 55 & 59 & 63 \\
\hline PT. Mandom Indonesia Tbk. (TCID) & 82 & 82 & 79 \\
\hline PT. Martina Berto Tbk. (MBTO) & 67 & 62 & 53 \\
\hline PT. Mustika Ratu Tbk. (MRAT) & 75 & 74 & 76 \\
\hline PT. Unilever Indonesia Tbk. (UNVR) & 31 & 28 & 27 \\
\hline \multicolumn{1}{c}{ Rata-Rata Industri } & $\mathbf{6 0}$ & $\mathbf{5 7 , 5}$ & $\mathbf{5 8}$ \\
\hline
\end{tabular}

Sumber: Data Sekunder Diolah, 2019

Berdasarkan Tabel 2 terlihat bahwa ADES pada periode 2015 hingga 2016 mengalami kestabilan nilai rasio dengan jumlah ekuitas dan aset yang meningkat; sedangkan pada tahun 2016 hingga 2017 nilai rasio perusahaan ini mengalami peningkatan sebesar 1,9\%. Hal ini menandakan bahwa peningkatan atau penambahan jumlah ekuitas dinilai baik, karena peningkatan yang terjadi menunjukkan bahwa adanya penambahan jumlah kekayaan perusahaan.

Tabel 2 menunjukkan KINO selama periode 2015 hingga 2016 juga mengalami peningkatan nilai rasio sebesar $6,7 \%$; sedangkan pada tahun 2016 hingga 2017 rasio ini kembali mengalami peningkatan sebesar $6,3 \%$. Dengan demikian, selama periode tiga tahun ini kekayan perusahaan mengalami peningkatan karena terjadinya penambahan jumlah ekuitas. Sementara itu, TCID pada periode 2015 hingga 2016 mengalami kestabilan nilai rasio pada besaran $82 \%$; tetapi pada tahun 2016 hingga 2017 mengalami penurunan nilai rasio sebesar 3,6\%.

Nilai rasio ekuitas terhadap total asset yang dicapai MBTO pada Tabel 2 selama periode 2015 hingga 2016 mengalami penurunan sebesar $7,4 \%$; tetapi pada tahun 2016 hingga 2017 nilai rasio tersebut kembali menurun sebesar $14,2 \%$. Hal ini menandakan penurunan atau pengurangan jumlah ekuitas dinilai tidak baik, karena penurunan yang terjadi menunjukkan adanya pengurangan jumlah kekayaan perusahaan.

Sementara itu, Tabel 2 menunjukkan nilai rasio ekuitas terhadap total asset dari MRAT pada periode 2015 hingga 2016 menurun sebesar $1,3 \%$; sedangkan pada tahun 2016 hingga 2017 nilai ROE yang dicapai mengalami peningkatan sebesar $2,6 \%$. Untuk 
capaian nilai rasio ini oleh UNVR pada periode 2015 hingga 2016 menurun sebesar 9,6\%; sedangkan pada tahun 2016 hingga 2017 mengalami penurunan kembali sebesar $3,5 \%$. Hal ini menandakan bahwa penurunan dan pengurangan jumlah ekuitas pada UNVR dinilai tidak baik, karena penurunan yang terjadi menunjukkan adanya pengurangan jumlah kekayaan perusahaan.

Berikutnya, berdasarkan rangkuman hasil perhitungan dalam Tabel 3 mengenai return on equity pada periode 2015 hingga 2017, ADES selama tiga tahun tersebut tidak mampu melampaui nilai rata-rata industri disebabkan jumlah laba yang dihasilkan mengalami fluktuasi. Sementara itu, KINO mengalami penurunan nilai ROE dengan keuntungan menurun selama periode tiga tahun sehingga tidak mampu melampaui nilai rata-rata industri.
Nilai ROE yang dicapai TCID pada Tabel 3 terlihat sempat melampaui nilai ratarata industri pada tahun 2015, tetapi untuk selanjutnya pada tahun 2016 hingga 2017 tidak mampu melampaui sebab laba yang dihasilkan mengalami fluktuasi. Selanjutnya, MBTO selama tiga periode memiliki nilai ROE yang berfluktuasi namun tidak mampu melampaui nilai rata-rata industri disebabkan laba yang dihasilkan olehnya turut mengalami fluktuasi.

Tabel 3 juga mengindikasikan bahwa MRAT mengalami laba yang berfluktuasi dan menyebabkan perrhitungan ROE menjadi rendah karena tidak dapat melampaui nilai rata-rata industri. Terakhir, UNVR dengan memiliki laba meningkat setiap tahunnya mampu mencapai nilai $\mathrm{ROE}$ yang terus meningkat dan mampu melampaui nilai untuk rata-rata industri.

Tabel 3. Return on Equity (ROE) Perusahaan Kosmetik di BEI Periode 2015 hingga 2017 (dalam persentase)

\begin{tabular}{lccc}
\hline \multicolumn{1}{c}{ Nama Perusahaan } & $\mathbf{2 0 1 5}$ & $\mathbf{2 0 1 6}$ & $\mathbf{2 0 1 7}$ \\
\hline PT. Akasha Wira International Tbk. (ADES) & 10 & 14,4 & 9 \\
\hline PT. Kino Indonesia Tbk. (KINO) & 14,8 & 9,2 & 5,3 \\
\hline PT. Mandom Indonesia Tbk. (TCID) & 31,75 & 9 & 9,6 \\
\hline PT. Martina Berto Tbk. (MBTO) & 3,23 & 1,85 & 5,9 \\
\hline PT. Mustika Ratu Tbk. (MRAT) & 0,27 & 1,5 & 0,3 \\
\hline PT. Unilever Indonesia Tbk. (UNVR) & 121,2 & 135,8 & 135,3 \\
\hline \multicolumn{1}{c}{ Rata-Rata Industri } & $\mathbf{3 0 , 2}$ & $\mathbf{2 8 , 6 2}$ & $\mathbf{2 7 , 5 6}$ \\
\hline
\end{tabular}

Sumber: Data Sekunder Diolah, 2019

Tabel 4. Debt to Equity Ratio (DER) Perusahaan Kosmetik di BEI Periode 2015 hingga 2017 (dalam persentase)

\begin{tabular}{lccc}
\hline \multicolumn{1}{c}{ Nama Perusahaan } & $\mathbf{2 0 1 5}$ & $\mathbf{2 0 1 6}$ & $\mathbf{2 0 1 7}$ \\
\hline PT. Akasha Wira International Tbk. (ADES) & 98,92 & 99,66 & 98,66 \\
\hline PT. Kino Indonesia Tbk. (KINO) & 80,74 & 68,25 & 57,53 \\
\hline PT. Mandom Indonesia Tbk. (TCID) & 21,41 & 22,54 & 27,09 \\
\hline PT. Martina Berto Tbk. (MBTO) & 49,44 & 60,78 & 89,14 \\
\hline PT. Mustika Ratu Tbk. (MRAT) & 31,84 & 30,87 & 35,61 \\
\hline PT. Unilever Indonesia Tbk. (UNVR) & 225.84 & 255,96 & 265,45 \\
\hline \multicolumn{1}{c}{ Rata-Rata Industri } & $\mathbf{8 4 , 6 9}$ & $\mathbf{8 9 , 6 7}$ & $\mathbf{9 5 , 5 8}$ \\
\hline
\end{tabular}

Sumber: Data Sekunder Diolah, 2019 
Tabel 5. Long Term Debt to Equity Ratio (LTDtER) Perusahaan Kosmetik di BEI Periode 2015 hingga 2017 (dalam kali)

\begin{tabular}{lccc}
\hline \multicolumn{1}{c}{ Nama Perusahaan } & $\mathbf{2 0 1 5}$ & $\mathbf{2 0 1 6}$ & $\mathbf{2 0 1 7}$ \\
\hline PT. Akasha Wira International Tbk. (ADES) & 36,43 & 47,89 & 38,50 \\
\hline PT. Kino Indonesia Tbk. (KINO) & 8,08 & 5,71 & 4,71 \\
\hline PT. Mandom Indonesia Tbk. (TCID) & 8,39 & 10,17 & 13,11 \\
\hline PT. Martina Berto Tbk. (MBTO) & 15,11 & 25,79 & 28,02 \\
\hline PT. Mustika Ratu Tbk. (MRAT) & 4,55 & 5,43 & 6,49 \\
\hline PT. Unilever Indonesia Tbk. (UNVR) & 16,05 & 24,72 & 23,20 \\
\hline \multicolumn{1}{c}{ Rata-Rata Industri } & $\mathbf{1 4 , 7 6}$ & $\mathbf{1 9 , 9 5}$ & $\mathbf{1 9}$ \\
\hline
\end{tabular}

Sumber: Data Sekunder Diolah, 2019

Tabel 4 menunjukkan rangkuman hasil perhitungan rasio utang terhadap modal atau DER dari perusahaan-perusahaan subsektor kosmetik selama periode 2015 sampai 2017. Berdasarkan table tersebut terlihat nilai DER yang dicapai ADES selama tiga tahun mampu melampaui nilai rata-rata industri namun mengalami fluktuasi. Di sisi lain, KINO mengalami penurunan nilai DER dan tidak mampu melampaui nilai rata-rata industri selama periode tiga tahun tersebut.

Tabel 4 selanjutnya menyatakan nilai DER yang diperoleh TCID tidak melampaui nilai rata-rata industri namun mengalami peningkatan selama periode tiga tahun itu. Sementara itu, MRAT mengalami nilai DER yang berfluktuasi tetapi tidak bisa melampaui nilai rata-rata industri. Terakhir, UNVR memiliki nilai DER yang meningkat setiap tahunnya dan nilai itu mampu melampaui nilai rata-rata industrinya.

Berikutnya, Tabel 5 merangkum hasil perhitungan nilai rasio LTDtER masingmasing perusahaan subsektor kosmetik di BEI yang diteliti. Berdasarkan tabel tersebut diperoleh nilai LTDtER selama periode 2015 hingga 2017 milik ADES mampu melampaui nilai rata-rata industrinya namun mengalami trend yang berfluktuasi. KINO sepanjang tiga tahun itu mengalami penurunan nilai LTDtER dan tidak mampu melampaui nilai rata-rata industri.

Tabel 5 juga mengidentifikasi bahwa nilai LTDtER yang dicapai TCID tidak melampaui nilai rata-rata industri namun mengalami peningkatan sepanjang periode tiga tahun analisis. Sementara MBTO selama tiga tahun memiliki nilai LTDtER yang meningkat dan mampu melampaui nilai ratarata industri. Nilai LTDtER milik MRAT terlihat mengalami peningkatan namun tidak dapat melampaui nilai rata-rata industri. UNVR bisa diidentifikasi memiliki nilai LTDtER yang berfluktuasi namun mampu melampaui nilai untuk rata-rata industri.

\section{KESIMPULAN}

Berdasarkan hasil analisis struktur modal dalam mengukur tingkat rentabilitas dan solvabilitas atas perusahaan-perusahaan subsektor kosmetik di tahun 2015-2017 terlihat bahwa total hutang yang dimiliki mengalami peningkatan dan keuntungan yang tercipta juga mengalami fluktuasi dari tahun ke tahun. Jika dilihat dari rata-rata standar industri untuk ROE, DER, dan LTDtER, nilai yang baik ditunjukkan pada tahun 2016 disebabkan laba yang dihasilkan merupakan nilai tertinggi bila dibandingkan dari periode 2015 ataupun periode 2017.

Periode 2015 merupakan periode yang terendah bagi nilai ROE, DER dan LTDtER. Berdasarkan objek penelitian pada enam perusahaan kosmetik, terlihat adanya satu perusahaan dengan pengelolaan struktur modal yang menghasilkan kinerja keuangan yang baik, yaitu UNVR dimana ROE, DER, dan LTDtER yang dicapai melampaui nilai rata-rata standar industri dan nilai yang dihasilkan itu lebih tinggi perolehannya dibandingkan perusahaan kosmetik lainnya. Sebaliknya, perusahaan yang memiliki nilai 
ROE, LTDtER dan DER yang rendah adalah KINO dan MRAT dimana nilai yang diperoleh tidak selalu dapat melampaui nilai rata-rata standar industri.

\section{DAFTAR PUSTAKA}

Brigham, E.F. dan Joel, F.H. 2010. DasarDasar Manajemen Keuangan. Alihbahasa: Ali Akbar Yulianto. Jakarta: Salemba Empat.

Gill, A., Nahum, B. dan Mathur, N. 2011. The Effect of Capital Structure on Profitability: Evidance from the United States. International Journal of Management. Vol. 28, No. 4, hal. 3-15. Harmono. 2011. Manajemen Keuangan.

Edisi Satu. Cetakan Kedua. Jakarta: PT. Bumi Aksara.

Hery. 2015. Analisis Kinerja Manajemen. Jakarta: PT. Grasindo.

Kasmir. 2015. Analisis Laporan Keuangan.

Edisi Satu. Cetakan Ketujuh. Jakarta: PT. RajaGrafindo Persada.
Kementrian Perindustrian Republik Indonesia. 2016. Kinerja Industri Kosmetik Nasional Lampaui Pertumbuhan Ekonomi. Jakarta: Kemenperin.

Mardiyanto, H. 2009. Intisari Manajemen Keuangan. Jakarta: PT. Grasindo.

Putra, R. 2009. Manajemen Keuangan dan Akuntansi untuk Eksekutif Perusahaan. Jakarta: Salemba Empat. Riyanto, B. 2008. Dasar-Dasar Pembelanjaan Perusahaan. Edisi Keempat. Yogyakarta: PT. BPFE.

Sartono, A. 2014. Manajemen Keuangan: Teori dan Aplikasi. Edisi Ketiga. Yogyakarta: BPFE.

Tsuji, C. 2013. Corporate Profitability and Capital Structure: The Case of the Machinery Industry Firm of the Tokyo Stock Exchange. International Journal of Business Administration. Vol. 4, No. 3, hal. 14-21.

www.idx.com (Diakses pada Senin, 20 Maret 2019). 